\title{
Diversity and ecology of Armillaria species in virgin forests in the Ukrainian Carpathians
}

\author{
Tetyana Tsykun • Daniel Rigling • Vitaliy Nikolaychuk • \\ Simone Prospero
}

Received: 20 September 2010 /Revised: 9 March 2011 /Accepted: 11 March 2011 /Published online: 13 April 2011

(C) German Mycological Society and Springer 2011

\begin{abstract}
In this study, we investigated the diversity and ecology of Armillaria species in virgin pure beech and mixed conifer forests $(15,000 \mathrm{ha})$ of the Carpathian Biosphere Reserve in Ukraine. Armillaria rhizomorphs were systematically sampled, both from the soil and from the root collar of trees (epiphytic), on 79 plots $(25 \times 20 \mathrm{~m})$ of a $1.5 \times 1.5 \mathrm{~km}$ grid. In both forest massifs, rhizomorphs were present in the majority of the soil samples, with an estimated dry weight of $512 \mathrm{~kg} / \mathrm{ha}$ in the pure beech forests and $223 \mathrm{~kg} / \mathrm{ha}$ in the mixed conifer forests. Similarly, in both forest massifs, most of the trees inspected had rhizomorphs at the root collar. Species identification based on DNA analyses showed that all five annulated European Armillaria species occur in these virgin forests, as previously observed in managed forests in central Europe. However, differences in the frequencies of the single species were observed. The predominance of the preferentially saprotrophic $A$. cepistipes and A. gallica (84 and 15\% of the specimens, respectively) and the absence of significant pathogenic activity suggest that in these virgin forests Armillaria species are most likely to behave as
\end{abstract}

T. Tsykun $\cdot$ D. Rigling $\cdot$ S. Prospero

Swiss Federal Institute for Forest,

Snow and Landscape Research WSL,

Zürcherstrasse 111,

CH-8903 Birmensdorf, Switzerland

T. Tsykun • V. Nikolaychuk

Uzhgorod National University,

Voloshyna str. 32,

88000 Uzhgorod, Ukraine

T. Tsykun $(\bowtie)$

Ostrivna str., 14/3,

88002 Uzhgorod, Ukraine

e-mail: tania_tsikun@yahoo.com saprotrophs. Forest management may increase the frequency of the pathogenic species $A$. ostoyae, which is rare in virgin forests.

Keywords Rhizomorphs · Wood-decaying fungi · Natural forests · The Carpathian Biosphere Reserve · Forest management

\section{Introduction}

The basidiomycete genus Armillaria (Fr.: Fr.) Staude is an important natural component of the mycoflora in forest ecosystems worldwide (Shaw and Kile 1991). All Armillaria species are able to survive saprotrophically by degrading woody substrates, and typically produce, in the soil or under the tree bark, highly differentiated filamentous aggregations named rhizomorphs (Garraway et al. 1991). Several species can also act as primary or secondary pathogens causing root rot on a wide range of trees and shrubs (Kile et al. 1991). At present, about 40 Armillaria species are known (Watling et al. 1991; Pegler 2000), 7 of which also occur in European temperate and boreal forests (Guillaumin et al. 1989; Zolciak et al. 1997). The individual species differ in ecological behavior, geographical distribution, and host preference (Shaw and Kile 1991).

The occurrence and ecology of Armillaria species have been well investigated in managed forest stands of western, southern, and south-eastern Europe (Guillaumin et al. 1993; Rigling et al. 1998; Tsopelas 1999; Prospero et al. 2003a; Keča et al. 2009; Oliva et al. 2009; Lushaj et al. 2010). In contrast, little detailed information is available for eastern European regions (Lochman et al. 2004; Łakomy 2006; Kaliszewski et al. 2007), and most studies only refer to Armillaria mellea sensu latu (e.g., Dudka et al. 1997). 
Moreover, since most European forest stands have been managed for centuries (Bengtsson et al. 2000), very little is known about the diversity, ecology, and distribution of Armillaria species in natural, undisturbed forest ecosystems in temperate Europe. The few remnants of natural forests that could be potentially investigated are not larger than 50-100 ha, while continuous forest areas of more than 1,000 ha are very rare.

In the Transcarpathian region of Ukraine (south-west), the Carpathian Biosphere Reserve (CBR) offers a unique opportunity for studying the biodiversity and natural processes in virgin or primeval forest ecosystems, i.e. forests that have never been significantly modified by human activity. The region covers an area of about 53,650 ha and became part of the World Network of Biospheres Reserves of UNESCO in 1992. It consists of six detached massifs and two botanical reserves (Brändli and Dowhanytsch 2003; Brändli et al. 2008; Hamor et al. 2008). About $80 \%$ of the CBR's territory is covered with mainly virgin (i.e., without any anthropogenic influences from the past; Parviainen 2005) or natural (i.e., naturally developing but with possible anthropogenic influences from the past; Parviainen 2005) forests that have never been clear-cut or artificially replanted (Brändli and Dowhanytsch 2003). Thus, the forest associations that occur there are probably representative of those in forests in central Europe prior to human influence. Oak (Quercus robur and $Q$. petraea) stands are predominant in the foothills, whereas at the mountainous level beech (Fagus sylvatica), mixed, and spruce (Picea abies, Abies alba) forests are present. Subalpine and alpine vegetation include pine (Pinus mugo) and green alder (Alnus viridis) forests and meadows. Regarding age structure, almost $50 \%$ of the CBR's stands can be considered mature and old overgrowth, with trees aged up to 250 years for beech and 400 years for silver fir (Hamor et al. 2008; Brändli and Dowhanytsch 2003). The forest area is characterized by a high abundance of dead wood in various stages of decay, which harbors a rich variety of fungal species involved in wood decomposition (Brändli et al. 2008).

Virgin forests are of interest for researchers because they have preserved their original structure and dynamics. Findings from studying these forests can benefit the close-to-nature management of exploited forests (Brändli et al. 2008). In natural forest ecosystems, native pathogenic organisms are thought to be important in regulating plant species diversity and distribution (Castello et al. 1995). Soil-borne fungal pathogens, such as the Armillaria species or Phellinus weirii, selectively remove the less vigorous trees, thereby producing canopy gaps and woody substrates which help forest regeneration (Holah et al. 1997; Bendel et al. 2006a). Artificial changes due to management practices (e.g., logging, modification of tree species composition) may greatly alter the ecological balance by increasing the impact of pathogens on forest structure and composition (Castello et al. 1995; Jactel et al. 2009). For example, when native forests are converted to exotic plantations, indigenous Armillaria species can cause considerable tree mortality (e.g., Armillaria root rot in Pinus radiata stands in New Zealand; Van der Pas 1981). The creation of fresh stumps through sylvicultural operations provides new food-bases for Armillaria species and stimulates the production of rhizomorphs in the soil (Stanosz and Patton 1991). Forest management may also modify the natural balance between different Armillaria species, sometimes resulting in pathogenic behavior by hitherto preferentially saptrotrophic species (Legrand et al. 1996).

The main aim of this study was to characterize the large-scale occurrence of Armillaria species in two virgin forest massifs (pure beech and conifer/mixed forests) of the CBR. Specifically, we: (1) quantified the presence of Armillaria rhizomorphs in the soil and on the root surface of trees; (2) assessed the impact of vegetation type, soil $\mathrm{pH}$, and altitude on the occurrence of Armillaria rhizomorphs; and (3) determined the composition of the Armillaria species community. These findings provided a basis for making inferences about the ecological role of the genus Armillaria in the virgin forests of the CBR.

\section{Materials and methods}

\section{Study area}

Our study was conducted in the core and buffer zones of two protected massifs (Uholsko-Shyrokoluzhanskyi and Chornohirskyi) of the CBR (Fig. 1). Here, forests, because of the absence of human activity (e.g., clear and selective cuttings, artificial plantations of non-indigenous trees, or livestock grazing), have preserved their natural structure and dynamic and can, therefore, be considered virgin (Shelyag-Sosonko 1997; Commarmot et al. 2005; Parviainen 2005; Brändli et al. 2008; Rizun and Chumak 2008).

In the Uholsko-Shyrokoluzhanskyi massif (10,383 ha), pure beech virgin forests occupy $88 \%$ of the total area and are included in UNESCO's World Heritage list. Typical characteristics of these forests are a high frequency of trees in the upper diameter classes $(30-80 \mathrm{~cm})$, a volume of standing and lying deadwood considerably higher than in comparable managed beech stands, and a small-scale gap dynamic (Commarmot et al. 2005). The massif, which consists of two contiguous areas (Uholka and Shyrokyi Lug forestry), is located between 400 and $1,350 \mathrm{~m}$ a.s.l., with the timberline at about $1,150 \mathrm{~m}$ a.s.l. (Brändli and Dowhanytsch 2003). The region is characterized by acidic 


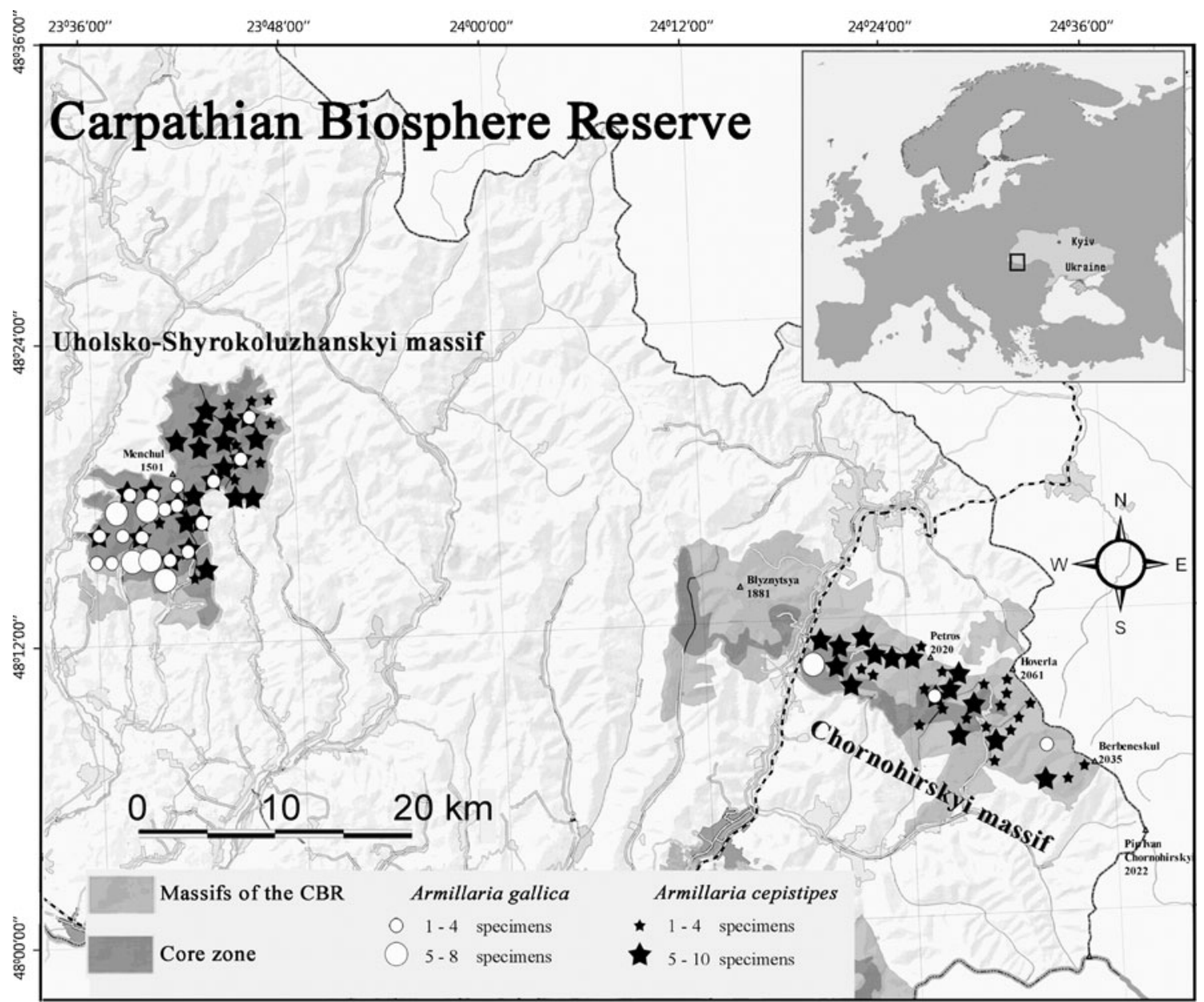

Fig. 1 Location of the two investigated protected forest massifs (Uholsko-Shyrokoluzhanskyi and Chornohirskyi) of the Carpathian Biosphere Reserve in south-western Ukraine and spatial distribution and frequency of Armillaria gallica and A. cepistipes rhizomorphs in the soil

brown soils (dystric cambisols) with high content of rough humus (12-15\%) in the upper horizons and a litter layer of about $5 \mathrm{~cm}$ (Voitkiv 2008; Hamor et al. 2008).

The climate is characterized by an annual average temperature of $+7^{\circ} \mathrm{C}$ and an annual average precipitation of $948 \mathrm{~mm}$ (Brändli and Dowhanytsch 2003). In the Uholka area, the annual temperatures are slightly higher and the vegetation period longer than in the Shyrokyi Lug area (Tasenkevich et al. 1982).

In the Chornohirskyi massif $(4,127 \mathrm{ha}), 67 \%$ of the forests are considered to be natural or virgin (Brändli and Dowhanytsch 2003). Most of the massif (79\%) is covered by coniferous mountain forests (fir-spruce forests) and mixed beech-fir-spruce forests (Hamor et al. 2008). The region lies between 700 and $2,061 \mathrm{~m}$ a.s.l., with the timberline at 1,500-1,550 m a.s.l. (Shelyag-Sosonko et al. 1997). Soils (dystric cambisols) are generally acidic but present a minor content of rough humus (10-12\%) in the upper horizons and a thinner litter layer $(3 \mathrm{~cm})$ than in the Uholsko-Shyrokoluzhanskyi massif (Voitkiv 2008; Hamor et al. 2008). The massif belongs to three different climate zones with annual average temperatures ranging from 0 to $+7^{\circ} \mathrm{C}$ and annual average precipitation varying between 1,000 and 1,500 mm (Brändli and Dowhanytsch 2003).

\section{Sampling}

In both forest massifs, Armillaria was systematically sampled on the plots of the $1.5 \times 1.5 \mathrm{~km}$ square grid of the large-scale inventory. Seventeen out of 96 plots were not included in the sampling because they were located outside the core or buffer zones of the protected massif, i.e., in areas where influences of past human activity could not be completely excluded. In each plot, a $20 \times 25 \mathrm{~m}\left(500 \mathrm{~m}^{2}\right)$ rectangle was established and samples of soil $(15 \times 15 \times$ $15 \mathrm{~cm}$ ) were taken at all four corners of the rectangle. The soil samples were sieved through a 9-mm square mesh to separate the roots and rhizomorphs from the soil (Prospero et al. 2003b). All rhizomorphs found were collected and taken to the laboratory where, for each soil sample, the number of individual rhizomorphs, their diameter, fresh 
weight, and dry weight (after lyophilisation for $12 \mathrm{~h}$ ) were determined. For $\mathrm{pH}$ measurement, $100 \mathrm{~g}$ of the sieved soil were taken at each sampling point. In addition, the nearest tree to each soil sampling point (i.e., four trees per plot) was checked for epiphytic rhizomorphs (i.e., rhizomorphs attached to the surface) on the root collar. Samples of these epiphytic rhizomorphs were then detached and the species identified in the laboratory.

In the lowland of the Uholsko-Shyrokoluzhanskyi massif, 20 Armillaria fruiting bodies were collected along a trail. Species identification showed that all belonged to $A$. gallica, apart from one which was of A. mellea. Giving that fruiting body sampling was not systematically conducted, these data were only used to confirm the presence of $A$. mellea in the investigated area.

\section{Armillaria isolation}

Armillaria was isolated from the rhizomorphs as described by Prospero et al. (2003a). Three segments $1 \mathrm{~cm}$ in length of one rhizomorph (randomly selected) from each soil sample and one epiphytic rhizomorph (randomly selected) from each tree were dipped in 50\% ethanol for 15-20 s. Subsequently, they were surface-sterilized in $30 \%$ hydrogen peroxide $\left(\mathrm{H}_{2} \mathrm{O}_{2}\right)$ for 25-40 s and placed on a semi-selective agar medium (12 g $1^{-1}$ malt extract, $15 \mathrm{~g}^{-1}$ Bacto Agar amended with $2 \mathrm{mg}^{-1}$ benomyl and $100 \mathrm{mg} 1^{-1}$ streptomycin; Maloy 1974). The isolation plates were incubated in the dark at $20-25^{\circ} \mathrm{C}$. After $1-3$ weeks, pure cultures were transferred to Diamalt agar $\left(15 \mathrm{~g}^{-1}\right.$ Bacto Agar, $20 \mathrm{~g} \mathrm{1^{-1 }}$ Diamalt; Hindelbank, Switzerland). All remaining rhizomorphs were frozen at $-20^{\circ} \mathrm{C}$ for genetic analyses.

\section{Soil $\mathrm{pH}$}

The $\mathrm{pH}$ of each soil sample was determined as described by Voznyuk and Kuzmich (1984). Briefly, 8 g of air-dry soil were dissolved in $20 \mathrm{ml}$ of distilled water and the actual acidity was determined at room temperature using a Knick pH-Meter 761 Calimatic.

\section{Species identification}

The first attempt to identify the Armillaria species involved conducting classic interfertility tests (Korhonen 1978) and PCR-RFLP analysis of a portion of the intergenic spacer (IGS-1) region of the ribosomal DNA (Harrington and Wingfield 1995). Many of the results were ambiguous. Thus, additional genetic analyses, i.e., sequencing of the IGS-1 and ITS regions of the ribosomal DNA, and PCRRFLP analysis and sequencing of the translational elongation factor 1- $\alpha$ region of the nuclear DNA, had to be conducted to identify the species clearly.
Interfertility tests Twenty-two unknown isolates were paired with three different haploid tester strains (Korhonen 1978) of the five annulated European Armillaria species (A. borealis Marxmuller and Korhonen, A. cepistipes (Velenovsky), A. ostoyae (Romagnesi) Herink, A. mellea (Vahl:Fr.) Kummer, A. gallica Marxmüller and Romagnesi) as described in Harrington et al. (1992). The tester strains originated from the mycological culture collection of WSL (Birmensdorf, Switzerland) and were initially provided by J.-J. Guillaumin (INRA, Clermont-Ferrand, France).

DNA extraction DNA was extracted from $50 \mathrm{mg}$ of lyophilized $(12 \mathrm{~h}$ ) rhizomorphs (one per soil sample and one per tree) and from $30 \mathrm{mg}$ of lyophilized $(12 \mathrm{~h})$ mycelium, which was obtained from 3-week-old Armillaria pure cultures on Diamalt agar. The extraction was performed using the CTAB method described in Gardes and Bruns (1993). The DNA was re-suspended in $50 \mu \mathrm{L}$ of TE buffer (10 mM Tris-HCl, $1 \mathrm{mM}$ EDTA, $\mathrm{pH}$ 8.0) and stored at $4^{\circ} \mathrm{C}$ until use.

PCR amplification The IGS-1 and the ITS (ITS-1, 5.8S, and ITS-2) regions of the ribosomal DNA and the translational elongation factor $1-\alpha(E F 1-\alpha)$ region of the nuclear DNA were amplified by PCR. The PCR reactions were performed in $50-\mu \mathrm{L}$ volumes with the following final concentrations: $1 \times$ reaction buffer (Sigma), $4 \mathrm{mM} \mathrm{MgCl}_{2}$, $100 \mu \mathrm{M}$ dNTPs (Promega), $20 \mathrm{pmol}$ of each primer (10 pmol for the ITS region), 2.5 U Taq DNA polymerase (Sigma), and about $50 \mathrm{ng}$ of DNA template. For each region, specific forward and reverse primers were used (IGS-1: LR12R and O-1, Veldman et al. 1981; Duchesne and Anderson 1990; ITS: ITS1 and ITS4, White et al. 1990; EF-1 $\alpha$ : EF595F and EF1160R, Maphosa et al. 2006). The IGS-1 and ITS regions were amplified using a PCR program with an initial denaturation at $95^{\circ} \mathrm{C}$ for $2 \mathrm{~min}$, followed by 35 cycles of $95^{\circ} \mathrm{C}$ for $30 \mathrm{~s}, 58^{\circ} \mathrm{C}$ for $30 \mathrm{~s}$, and $72^{\circ} \mathrm{C}$ for $2 \mathrm{~min}$, and 1 cycle of $72^{\circ} \mathrm{C}$ for $30 \mathrm{~min}$. For amplification of the EF1- $\alpha$ region, the following PCR program was used: 1 cycle of $94^{\circ} \mathrm{C}$ for $2 \mathrm{~min}$, followed by 33 cycles of $94^{\circ} \mathrm{C}$ for $30 \mathrm{~s}, 55^{\circ} \mathrm{C}$ for $30 \mathrm{~s}$, and $72^{\circ} \mathrm{C}$ for $2 \mathrm{~min}$, and 1 cycle of $72^{\circ} \mathrm{C}$ for $30 \mathrm{~min}$. The PCR products were checked for successful amplification and their length was determined in $1.5 \%$ agarose gels.

RFLP analysis For species identification, the PCR products of the IGS-1 region were digested with the four restriction enzymes Alu I, Hinc II (Hind II), Mva1269 I (Bsm I), and Nde I (Fermentas) (Harrington and Wingfield 1995). The digest was performed according to the manufacturer's protocol using $10 \mu \mathrm{L}$ of the PCR product. The sizes of the restriction fragments were determined on 3\% agarose gels after running at $99 \mathrm{~V} / \mathrm{cm}$ for $50 \mathrm{~min}$. Species 
identification was considered successful if the resulting pattern corresponded to one of the previously described patterns for the five annulated European Armillaria species (Harrington and Wingfield 1995; Kim et al. 2000; Keča et al. 2006; Pérez-Sierra et al. 1999). Samples with a mixed $A$. cepistipes and $A$. gallica RFLP pattern in the IGS-1 region were further analyzed in the EF1- $\alpha$ region by digesting the EF1- $\alpha$ amplicon (approx. $600 \mathrm{bp)}$ ) with the restriction enzyme $A l u \mathrm{I}$. The three haploid tester strains of $A$. cepistipes and A. gallica previously used for interfertility tests served as references for the EF1- $\alpha$ RFLP analysis. Samples that showed the same pattern as the three $A$. cepistipes testers (i.e. two bands of approx. 444 and $156 \mathrm{bp}$ ) were considered to belong to A. cepistipes, and samples with the same pattern as the three A. gallica testers (i.e. two bands of approx. 560 and $40 \mathrm{bp}$ ) were considered to be $A$. gallica.

Sequencing of the IGS-1, ITS, and EF-1 $\alpha$ regions The PCR products were purified using PCR purification columns (MinElute PCR Purification Kit; Qiagen, Valencia, CA, USA) according to the manufacturer's recommendations. Sequencing reactions were carried out with the BigDye Terminator Cycle Sequencing Reaction v3.1 Kit (Applied Biosystems, Carlsbad, CA, USA) following the protocol provided by the manufacturer. Post-reaction clean-up was performed using DTR Gel Filtration Cartridges (Edge BioSystems, Gaithersburg, MD, USA) according to the manufacturer's protocol. Each region was sequenced separately in both directions using the above-mentioned specific primers. The sequences were generated using an ABI 3130 sequencer (Applied Biosystems). All sequences were edited manually using the software GeneStudio (TM) Professional Edition Version 2.1.2.3, and then analyzed with CLC Sequence Viewer Version: 4.6.1 (CLC bio).

\section{Statistical analysis}

The data were analysed statistically with the software JMP 8 (SAS Institute). For an effect to be considered statistically significant, we used a level of significance of $5 \%(p<0.05)$. The relationship between dry weight, diameter, and the number of rhizomorphs in the soil (dependent variables) and the altitude and soil $\mathrm{pH}$ of the plots (independent variables) was analysed using a multiple regression analysis ( $B=$ regression coefficient, $R=$ coefficient of multiple correlation, $r^{2}=$ coefficient of multiple determination, and $p=$ probability of error). The relationship between the presence of epiphytic rhizomorphs on the roots (yes/no) and the amount of rhizomorphs in the corresponding soil samples (dry weight) was investigated with Pearson's coefficient of correlation $r$. Finally, the relationship between the presence of epiphytic rhizomorphs (dependent variable) and the altitude and soil $\mathrm{pH}$ of the plots (independent variables) was investigated with logistic regression. The frequencies of $A$. cepistipes and $A$. gallica rhizomorphs in the soil and on the root surface of trees were compared using chi-square.

\section{Results}

Incidence of Armillaria rhizomorphs

Armillaria rhizomorphs were found in all 79 sample plots in the two forest massifs, in a total of 216 soil samples $(68 \%)$ and on the roots of 240 trees $(76 \%)$. In the massif with pure beech forests, rhizomorphs were present in $85 \%$ of the soil samples and on the root collar of $81 \%$ of the inspected trees (Table 1). In the conifer and mixed forest massif, rhizomorphs showed a lower frequency and were more frequent on the root collars $(65 \%$ of the observed trees) than in the soil (53\% of total samples). Consequently, the estimated total rhizomorph biomass in the soil was considerably higher in the pure beech forests $(512 \mathrm{~kg} / \mathrm{ha})$ than in the conifer and mixed forests $(223 \mathrm{~kg} /$ ha). Within the same soil $\mathrm{pH}$ class and altitudinal range, the rhizomorph biomass in the soil was about three times higher in the pure beech forests than in the conifer and mixed forests.

Multiple regression analyses showed that, in both massifs, the altitude of the plots significantly affected the amount of rhizomorphs (dry weight and number) in the soil (Table 1). The frequency of rhizomorphs in the soil and on the surface of the root collar significantly decreased with increasing altitude (Fig. 2a). In the pure beech forest massif, $80 \%$ of all soil rhizomorph dry mass was found at altitudes between 500 and $910 \mathrm{~m}$ a.s.l., but in proximity to the timberline $(1,000 \pm 150 \mathrm{~m}$ a.s.l.) rhizomorphs were less frequent. The same trend was observed in the conifer and mixed forest massif with an altitude correction due to the different altitude of the timberline ( $80 \%$ of the rhizomorph's mass found between 590 and $1,350 \mathrm{~m}$ a.s.1.; rhizomorphs were rare above $1,400 \mathrm{~m}$ a.s. 1.). Similarly, epiphytic rhizomorphs on the root collars were significantly less frequent at high altitudes (Fig. 2a). In the massif with pure beech forests, up to $1,000 \mathrm{~m}$ a.s.1. 92\% of the inspected beech trees had Armillaria rhizomorphs on their root collars. Near the timberline $(1,000 \pm$ $150 \mathrm{~m}$ a.s.1.) only $75 \%$ of the trees were positive for rhizomorphs. In the conifer and mixed forest massif, below 1,400 $\mathrm{m}$ a.s.l. epiphytic rhizomorphs were present on the root collars of $77 \%$ of the trees, whereas near the timberline (approx. 1,400 m a.s.l.) they were only on $39 \%$ of the trees (Table 1). 
Table 1 Characteristics of the Armillaria rhizomorphs found in the soil and epiphytically on the roots of trees in the UholskoShyrokoluzhanskyi (pure beech forests) and in the Chornohirskyi (conifer and mixed forests) massifs in the Carpathian Biosphere Reserve in Ukraine and influence of altitude of the plots, soil $\mathrm{pH}$, and altitude $\times$ soil $\mathrm{pH}$ on their abundance

\begin{tabular}{|c|c|c|}
\hline Rhizomorphs & Beech forests & $\begin{array}{l}\text { Conifer/mixed } \\
\text { forests }\end{array}$ \\
\hline \multicolumn{3}{|l|}{ In the soil } \\
\hline Incidence of positive sample points & $140 / 172(81 \%)$ & $76 / 144(53 \%)$ \\
\hline Mean weight per sample, $g$ & $1.18 \pm 0.08$ & $0.51 \pm 0.06$ \\
\hline Biomass (dry weight), $\mathrm{kg} / \mathrm{ha}$ & 520 & 226 \\
\hline Mean rhizomorph diameter per sample, $\mathrm{mm}$ & $1.17 \pm 0.05$ & $0.82 \pm 0.05$ \\
\hline Altitudinal range with the majority of rhizomorphs, $\mathrm{m}$ a.s.l. ( $80 \%$ of total dry weight) & $500-910$ & $590-1,350$ \\
\hline $\mathrm{pH}$ range with the majority of rhizomorphs ( $80 \%$ of total dry weight) & $3.5-5.0$ & $4.0-5.0$ \\
\hline Influence of altitude of the plots ${ }^{\mathrm{a}}$ & $r=-0.42, r^{2}=0.18, p<0.0001$ & \\
\hline Influence of soil $\mathrm{pH}^{\mathrm{a}}$ & $r=0.28, r^{2}=0.08, p=0.012$ & \\
\hline \multirow[t]{2}{*}{ Influence of altitude of the plots $\times$ soil $\mathrm{pH}^{\mathrm{b}}$} & $R=0.54, r^{2}=0.26, p<0.0001$ & \\
\hline & $\mathrm{BpH}=0.33$, Balt $=-0.46$ & \\
\hline \multicolumn{3}{|l|}{ Epiphytic on the roots } \\
\hline Incidence of positive trees & $146 / 172(85 \%)$ & $94 / 144(65 \%)$ \\
\hline Altitudinal range with $80 \%$ of all positive trees (m a.s.l.) & $500-970$ & $590-1,350$ \\
\hline Frequency of positive trees ( $\%$ of inspected trees) & 97 & 78 \\
\hline Frequency of positive trees above the altitudinal range ( $\%$ of inspected trees $)$ & 75 & 43 \\
\hline Influence of altitude of the plots ${ }^{\mathrm{a}}$ & $r=-0.36, r^{2}=0.13, p<0.0001$ & \\
\hline Influence of soil $\mathrm{pH}^{\mathrm{a}}$ & $r=0.06, r^{2}=0.004, p=0.26$ & \\
\hline \multirow[t]{2}{*}{ Influence of altitude of the plots $\times$ soil $\mathrm{pH}^{\mathrm{b}}$} & $R=0.37, r^{2}=0.136, p<0.0001$ & \\
\hline & $\mathrm{BpH}=0.093$, Balt $=-0.37$ & \\
\hline
\end{tabular}

${ }^{\mathrm{a}} r$ Pearson's coefficient of correlation; $r^{2}$ coefficient of determination; $p$ probability of error

${ }^{\mathrm{b}} R$ coefficient of multiple correlation; $r^{2}$ coefficient of multiple determination; $B$ regression coefficient; $p$ probability of error

In both massifs, the amount of rhizomorphs (dry weight) in the soil was also affected by the soil $\mathrm{pH}$ (Table 1). Most rhizomorphs (74\% of total dry weight) were found in plots with soil $\mathrm{pH}$ between 4.0 and 5.0, and less than 5\% below pH 3.5 and above pH 5.5 (Fig. 2b). In contrast, the soil $\mathrm{pH}$ had no significant influence on the frequency of epiphytic rhizomorphs on the root collars (Table 1).
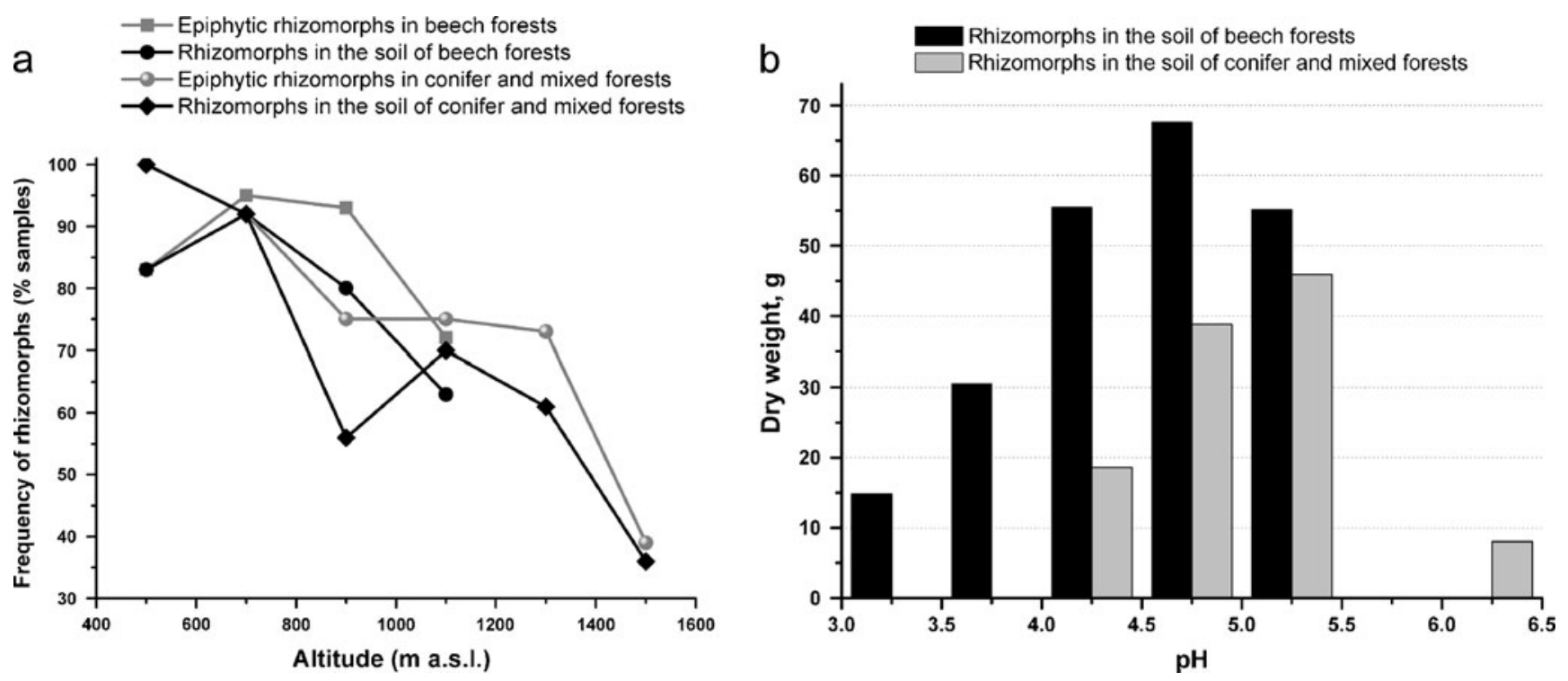

Fig. 2 Relationship between the presence of Armillaria rhizomorphs and a plot altitude (soil and epiphytic rhizomorphs) and b soil pH (soil rhizomorphs) in beech forests and conifer/mixed forests in the Uholsko-Shyrokoluzhanskyi and Chornohirskyi massifs 
The simultaneous presence of rhizomorphs in a soil sample and on the root collar of the nearby standing tree was observed at $85 \%$ of the sample points in the beech forests and for $74 \%$ in the conifer and mixed forests (Fig. 3). Pearson's correlation tests showed that the presence of epiphytic rhizomorphs on the root collars was significantly correlated to the presence of rhizomorphs in the soil $(r=0.46, p<0.0001)$.

\section{Armillaria species identification}

In total, 424 rhizomorphs could be assigned to an Armillaria species. Armillaria cepistipes was the dominant species ( $84 \%$ of the specimens), followed by $A$. gallica ( $15 \%$ of the specimens). The remaining $1 \%$ of the specimens were classified as $A$. ostoyae (five specimens) or $A$. borealis (one specimen). The two rare species were easily discriminated using interfertility tests and a PCR-RFLP analysis of the IGS-1 region. In fact, the same restriction fragment patterns were observed as previously reported for European Armillaria species (Harrington and Wingfield 1995; Kim et al. 2000; Keča et al. 2006; Pérez-Sierra et al. 1999). In contrast, the identification of the two genetically, morphologically and ecologically close $A$. cepistipes and $A$. gallica was much more problematic. Interfertility tests for some isolates gave ambiguous results and sequencing the IGS-1 and ITS amplicons revealed heterogeneous intraspecific and interspecific variations in $35 \%$ of the specimens. These problematic specimens could only be assigned to either $A$. cepistipes or A. gallica by performing sequence and PCR-RFLP analyses of the EF $1-\alpha$ region. The EF1 $\alpha$ region of the three tester strains of both $A$. cepistipes and A. gallica were sequenced

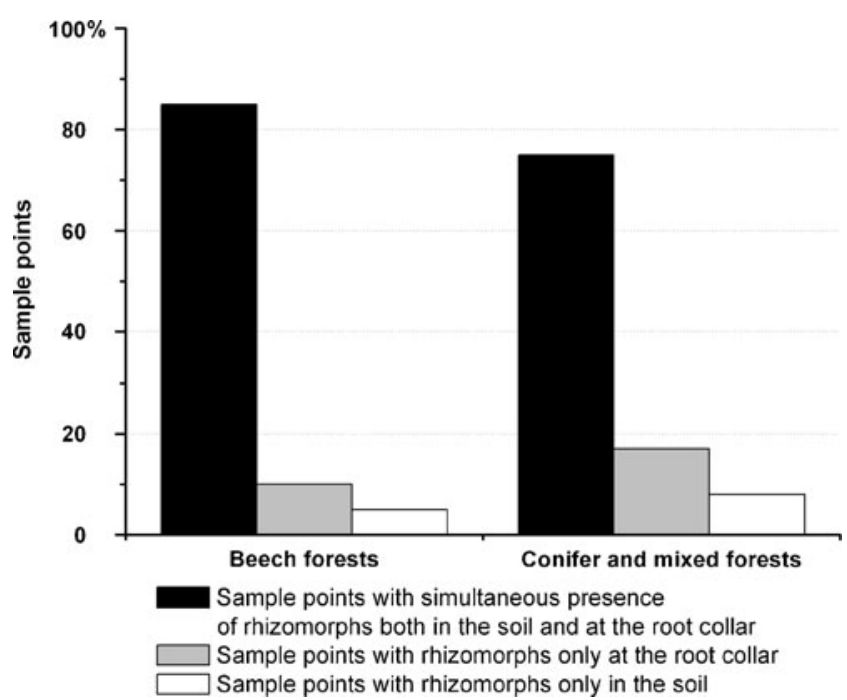

Fig. 3 Incidence of Armillaria rhizomorphs in a soil sample and on the root collar of the nearby tree in beech forests and in mixed conifer forests in the Uholsko-Shyrokoluzhanskyi and Chornohirskyi massifs beforehand. A restriction enzyme was then identified (Alu I) that produced different fragment patterns for the two species (A. cepistipes: approx. 560 and $44 \mathrm{bp} ;$ A. gallica: approx. 444 and $156 \mathrm{bp}$ ). All PCR products of the EF1- $\alpha$ region of the problematic specimens were digested with Alu I, and only one of the two expected patterns (A. cepistipes or $A$. gallica) were observed from each specimen.

\section{Armillaria species ecology}

The five A. ostoyae specimens (rhizomorphs) were collected at four different locations in the pure beech forest massif. Three rhizomorphs were found in two plots on the root collar surface of three beech trees at an altitude ranging from 600 to $700 \mathrm{~m}$ a.s.1, whereas two rhizomorphs were found in the soil in two plots at 1,000-1,100 $\mathrm{m}$ a.s.l. and with a soil $\mathrm{pH} 4.01-5.0$. The single $A$. borealis rhizomorph found originated from a soil sample $(\mathrm{pH} 4.74)$ taken in a plot (1,210 $\mathrm{m}$ a.s.1.) dominated by silver fir (Abies alba) in the conifer forest massif.

The two dominant species, A. cepistipes and A. gallica, were found both in the soil and epiphytically on the root collars of trees (Table 2). In $67 \%$ of the plots only $A$. cepistipes occurred, in 4\% only $A$. gallica and in $27 \%$ both species. When considering only the plots with either $A$. cepistipes or $A$. gallica, the estimated rhizomorph biomass (dry weight) in the soil was similar for both species, i.e., $397 \mathrm{~kg} / \mathrm{ha}$ for $A$. cepistipes and $384 \mathrm{~kg} / \mathrm{ha}$ for $A$. gallica. In plots with both species co-occurring, the same species was observed in the soil and on the root surface in $70 \%$ of the sample points. Based on a chi-square test, the frequencies of both Armillaria species in the soil and on the root collars were not significantly different $\left(\chi^{2}=0.09, p=0.76\right)$.

Armillaria cepistipes was the dominant species at all altitudes in all the forest associations investigated. Compared to A. gallica, A. cepistipes was more frequent at higher altitudes (up to 1,500 $\mathrm{m}$ a.s.1.) and in soils with a $\mathrm{pH}$ ranging from 3.5 to 5.5 (Table 3). Armillaria gallica was preferentially found ( $76 \%$ of the specimens) in the pure beech forest of the Uholka area in the Uholsko-Shirokoluzhanskyi massif (Fig. 1). Most A. gallica rhizomorphs (96\%) were collected in plots at low altitudes (509-1,060 m a.s.1.), with only one specimen collected in a Piceetum-abietis stand at $1,480 \mathrm{~m}$ a. s.1. Almost $67 \%$ of the $A$. gallica soil rhizomorphs originated from acid soils ( $\mathrm{pH} 3.0-4.51$ ), and no rhizomorphs of this species were found in soils with a $\mathrm{pH}>5.4$ (Table 3).

\section{Discussion}

In this study, we investigated the occurrence and distribution of Armillaria species in two virgin forest massifs in the Ukrainian Carpathians by systematically 
Table 2 Incidence of Armillaria cepistipes and A. gallica rhizomorphs in the soil and on the root collar of trees (epiphytic rhizomorphs) in the different forest associations present in the Uholsko-Shyrokoluzhanskyi and Chornohirskyi forest massifs

\begin{tabular}{|c|c|c|c|c|c|c|c|}
\hline $\begin{array}{l}\text { Protected } \\
\text { massif }\end{array}$ & $\begin{array}{l}\text { Forest } \\
\text { association }^{\mathrm{a}}\end{array}$ & Plots $(n)$ & $\begin{array}{l}\text { Inspected } \\
\text { trees }(n)\end{array}$ & $\begin{array}{l}\text { Dry weight of soil } \\
\text { rhizomorphs }{ }^{\mathrm{b}} \\
\text { (g/plot) }\end{array}$ & $\begin{array}{l}\text { Frequency of trees } \\
\text { with epiphytic } \\
\text { rhizomorphs }\end{array}$ & $\begin{array}{l}\text { A. cepistipes, } \\
\text { rhizomorphs } \\
\text { (epiphytic/soil) }^{\mathrm{c}}\end{array}$ & $\begin{array}{l}\text { A. gallica, } \\
\text { rhizomorphs } \\
\text { (epiphytic/soil) }^{c}\end{array}$ \\
\hline $\begin{array}{l}\text { Uholsko- } \\
\text { Shyrokoluzhanskyi }\end{array}$ & Fagetum (silvaticae) & 40 & 160 & $4.79 \pm 1.54$ & 0.88 & $100 / 89$ & $31 / 20$ \\
\hline Chornohirskyi & $\begin{array}{l}\text { Other broadleaved } \\
\text { associations }\end{array}$ & 3 & 12 & $2.19 \pm 0.44$ & 1.00 & $10 / 7$ & $2 / 4$ \\
\hline Chornohirskyi & Piceetum (abietis) & 19 & 76 & $1.92 \pm 0.85$ & 0.62 & $44 / 36$ & $1 / 0$ \\
\hline $\begin{array}{l}\text { Uholsko- } \\
\text { Shyrokoluzhanskyi } \\
\text { and Chornohirskyi }\end{array}$ & $\begin{array}{l}\text { Other mixed conifer } \\
\text { and broadleaved } \\
\text { associations }\end{array}$ & 12 & 48 & $3.08 \pm 1.62$ & 0.81 & $29 / 23$ & $0 / 5$ \\
\hline \multirow[t]{2}{*}{ Chornohirskyi } & $\begin{array}{l}\text { Other conifer } \\
\text { associations }\end{array}$ & 5 & 20 & $0.89 \pm 0.11$ & 0.50 & $9 / 8$ & $0 / 0$ \\
\hline & Total & 79 & 316 & - & - & $192 / 163$ & $34 / 29$ \\
\hline
\end{tabular}

${ }^{\text {a }}$ According to Shelyag-Sosonko et al. (1997)

${ }^{\mathrm{b}}$ Mean values and standard errors are given

${ }^{\mathrm{c}}$ Number of epiphytic rhizomorphs/Number of soil rhizomorphs

sampling rhizomorphs in the soil and on the root collars of trees (epiphytic rhizomorphs).

The high abundance of rhizomorphs suggests that the genus Armillaria is an important component of the mycoflora in the virgin forests investigated, where it most likely plays a significant role as a wood decomposer. This hypothesis is supported by (1) the total absence of remarkable tree mortality caused by pathogenic fungi, and (2) the predominance of the preferentially saprotrophic Armillaria species. In the region studied, A. cepistipes is the most frequent species, followed by A. gallica. Armillaria ostoyae, A. borealis, and A. mellea are also present, but their frequency is very low. Thus, our study confirms the presence of all five annulated European Armillaria species in south-western Ukraine, as previously reported for the neighboring countries (Łakomy 2006; Kaliszewski et al. 2007; Antonin et al. 2009).

The two predominant species, A. cepistipes and $A$. gallica, are considered to be preferential saprotrophs, forming dense networks of rhizomorphs in the soil (Guillaumin et al. 1993; Rigling et al. 1998; Prospero et al. 2003b). Through soil rhizomorphs they may reach new, still unexploited resources (i.e., food bases), such as living trees. Our study indicates that, in natural, unmanaged beech and conifer/mixed forests, whenever A. cepistipes and $A$. gallica rhizomorphs are present in the soil, they are also most likely to be found epiphytically on the root collars of living trees. Abundant epiphytic rhizomorphs of A. gallica and $A$. cepistipes have been previously reported from the root collars of various tree species, including pedunculate oak (A. gallica; Marçais and Caël 2006), sugar maple ( $A$. gallica; Marçais and Wargo 2000), and Norway spruce ( $A$. cepistipes; Prospero et al. 2003a). Given that healthy trees can usually prevent colonization of their roots by $A$. cepistipes and A. gallica, epiphytic rhizomorphs of these two species probably wait until conditions are favorable to penetrate the bark. In managed forests, bark penetration usually happens after trees are felled and fresh stumps are created (Prospero et al. 2006). In unmanaged natural forests, roots may be penetrated by Armillaria when trees are broken or uprooted by strong winds or weakened by drought or defoliating insects (Marçais and Bréda 2006). Why soil rhizomorphs are more abundant in pure beech forests than in conifer and mixed forests probably has not solely to do with differences in altitude and soil $\mathrm{pH}$. In fact, even within the same altitude and soil $\mathrm{pH}$ class, soil rhizomorphs are generally more abundant in pure beech forests than in conifer and mixed forests. Thus, it seems likely that vegetation type plays an important role. Previous studies have shown that the density of rhizomorphs is increased by the presence of woody substrates, such as small woody debris, understory vegetation, and root fragments (Lamour et al. 2007). Supporting these observations, in the pure beech forests we investigated, woody substrates were more abundant than in the conifer and mixed forests (Hamor et al. 2008). Comparing our data on abundance of soil and epiphytic rhizomorphs with those from managed forests is difficult because of the absence of similar studies. In managed Norway spruce stands in the Swiss Alps, Prospero et al. (2003a) found that the rhizomorph network formed by $A$. cepistipes can be very dense, reaching up to $25 \mathrm{~m} / \mathrm{m}^{2}$. Similarly, Stanosz and Patton (1991) evidenced an abundant presence of soil rhizomorphs around stumps in managed aspen (Populus spp.) stands in Wisconsin. Both in natural and managed forests, the abundance of rhizomorphs in the soil and on the roots of living trees may give 
Armillaria an advantage over other wood-decaying fungi in acquiring new resources immediately after these are produced by anthropogenic or natural forest disturbances.

Although A. cepistipes and A. gallica are ecologically very similar, their occurrence in the two forest massifs differed. While A. cepistipes was the dominant species in all the forest types investigated, A. gallica was mainly restricted to the pure beech forests at low altitudes. Within the beech forest massif, A. gallica rhizomorphs were more frequent in the Uholka area where annual temperatures are slightly higher and the vegetation period longer than in the Shyrokyi Lug area. This distribution pattern of the two species supports previous findings indicating that $A$. gallica is generally confined to hardwood forests at low altitudes, while A. cepistipes can occur in both hardwood and coniferous forests (Guillaumin et al. 1993; Tsopelas 1999; Prospero et al. 2003b; Keča et al. 2009). Our study suggests that soil $\mathrm{pH}$ may also be a selective factor for the occurrence of either A. cepistipes or A. gallica. The relatively greater sensitivity of $A$. cepistipes to soil acidity compared to $A$. gallica may give the latter an advantage in occupying acidic soils in forests where, according to the vegetation type and altitude, both species could theoretically occur. However, additional data would be necessary to better understand the factors affecting the distribution of these two species. In about $27 \%$ of the plots, A. cepistipes and A. gallica co-occurred. The sympatrical co-existence of these two species was also observed in pure beech forests in Central France (Legrand et al. 1996), but it seems to be relatively rare. More frequently reported is the co-existence in the same stand of species characterized by a different ecological behavior, such as A. cepistipes and A. ostoyae (Prospero et al. 2003b; Bendel et al. 2006b) or A. gallica and A. mellea (Baumgartner and Rizzo 2001).

The ecological similarity between $A$. cepistipes and $A$. gallica might account for the high genetic and morphologic (i.e., fruiting bodies) similarities. Our study confirms that the two species can hardly be discriminated using traditional methods (interfertility tests, analysis of IGS and ITS). Based on our results and those of previous studies (Maphosa et al. 2006; Antonin et al. 2009), A. cepistipes and A. gallica can be distinguished by PCR-RFLP analysis of the EF- $1 \alpha$ region. This method was the only one that gave unambiguous results with our isolates.

Armillaria borealis and A. ostoyae were also identified among the rhizomorphs sampled. Since a few fruiting bodies of A. mellea were also found in the UholskoShyrokoluzhanskyi massif, our study indicates that all five annulated European Armillaria species are present in the Ukrainian Carpathians. Previously, only A. mellea s.l. was described for this region (Dudka et al. 1997). As the frequency of Armillaria species was estimated based on the abundance of rhizomorphs in the soil and on the root collar 
of trees, an objection could be that the incidence of the pathogenic, less rhizomorph-producing species $A$. ostoyae and A. mellea may have been underestimated. However, sampling rhizomorphs has been shown to be appropriate for detecting A. ostoyae in mixed conifer forests in the Alps (Prospero et al. 2003b) or in pure and mixed beech forests in Central France (Legrand et al. 1996). In addition, on all the plots of the two massifs, no tree mortality caused by Armillaria infections was observed. Generally, forests in these protected regions can be described as stable and selfregenerating ecosystems in the climax stage of succession (Rizun and Chumak 2008). The only ecological niche for Armillaria not considered in the sampling design we used was heart rot. As previous studies have reported the presence of both pathogenic (A. ostoyae) and preferentially saprotrophic (A. cepistipes) species in decayed heartwood (Piri et al. 1990; Prospero et al. 2003a), this omission should not greatly modify our results.

The mainly saprotrophic Armillaria borealis was found only once and it probably plays a marginal ecological role in these particular forest ecosystems. Previous investigations indicated that A. ostoyae is mainly associated with conifers and can behave as an aggressive pathogen in managed stands (Mallett and Maynard 1998; Lung-Escarmant and Guyon 2004; Lushaj et al. 2010). In undisturbed stands and in beech or beech-fir stands, however, A. ostoyae may in contrast occur as a saprotroph or a secondary parasite (Guillaumin et al. 1989; Legrand and Guillaumin 1993; Tsopelas 1999). Surprisingly, we only found $A$. ostoyae rhizomorphs in pure beech forests, both in the soil (two plots) and epiphytically on the root collar (two plots), and their presence was never related to visible tree mortality. In the CBR's forests, $A$. ostoyae, like A. cepistipes and A. gallica, seems to preferentially behave as a saprotroph and rarely as a secondary/opportunistic parasite. Because of its frequent pathogenicity toward conifers, A. ostoyae might be an important regulator of stand composition, leading forest succession in the direction of stable pure beech stands. However, as $A$. ostoyae shows significant intraspecific differences in virulence (Morrison and Pellow 2002; Prospero et al. 2004), to support such a hypothesis the virulence of the local genotypes toward conifers should be determined by performing inoculation tests.

In conclusion, our study indicates that, in virgin, unmanaged beech and mixed conifer forests in continental Europe, Armillaria is a very frequent saprotroph. By forming a dense network of rhizomorphs in the soil, Armillaria reaches the roots of living trees and occupies their surface with rhizomorphs. This strategy may allow Armillaria to rapidly colonize the roots and the root collars as soon as the trees are weakened by other factors. Given that wood-decaying fungi are essential for the functioning of forest ecosystems (Lonsdale et al. 2008), Armillaria may play an important ecological role in virgin forests. Although in the two protected forest massifs the same Armillaria species were observed as have been found in managed forests in central Europe, the frequencies of the single species differ. In particular, this applies to A. ostoyae, which in Europe has a very broad distribution range, from sea level in south-western France up to the timberline in the Alps (Guillaumin et al. 1993; Bendel et al. 2006a). Its higher frequency in managed forests compared to virgin forests may be a consequence of intensive forest management. Starting from the end of the eighteenth century, the frequent replacement of broadleaved tree species (especially beech) with conifers (especially Norway spruce and Pinus species) and the production of fresh food bases (stumps) could have created more favorable conditions for A. ostoyae. As modern and sustainable forest management aims to re-convert these coniferous monocultures into natural broadleaved stands (Farrell et al. 2000), detailed knowledge about the diversity and ecology of Armillaria species in virgin forests will help us to understand changes in the Armillaria community after forest re-conversion.

Acknowledgements We would like to thank the WSL institute and the Swiss National Science Foundation for financial support and Brigitte Commarmot for successfully leading the Ukrainian-Swiss scientific cooperation project. We are grateful to Vasyl Chumak for organizing the research in Ukraine, Dmytro Symochko, Iryna Kovalenko, and all foresters for field assistance, and the director of the CBR Hamor Fedir, who made the fieldwork possible. We also thank Esther Jung and Hélène Blauenstein for technical support in the laboratory, Francesco Dal Grande for scientific support, and Silvia Dingwall for English revision of the manuscript.

\section{References}

Antonin V, Tomšovský M, Sedlák P, Májek T, Jankovský L (2009) Morphological and molecular characterization of the Armillaria cepistipes - A. gallica complex in the Czech Republic and Slovakia. Mycol Prog 8:259-271

Baumgartner K, Rizzo DM (2001) Ecology of Armillaria spp. in mixed-hardwood forests of California. Plant Dis 85:947951

Bendel M, Kienast F, Bugmann H, Rigling D (2006a) Incidence and distribution of Heterobasidion and Armillaria and their influence on canopy gap formation in unmanaged mountain pine forests in the Swiss Alps. Eur J Plant Pathol 116:85-93

Bendel M, Kienast F, Rigling D (2006b) Genetic population structure of three Armillaria species at the landscape scale: a case study from Swiss Pinus mugo forests. Mycol Res 110:705-712

Bengtsson J, Nilsson SG, Franc A, Menozzi P (2000) Biodiversity, disturbances, ecosystem function and management of European forests. For Ecol Manag 132:39-50

Brändli UB, Dowhanytsch J (2003) Urwälder im Zentrum Europas. Ein Naturführer durch das Karpaten-Biosphärenreservat in der Ukraine. Eidgenössische Forschungsanstalt WSL, Birmensdorf; Karpaten-Biosphärenreservat, Rachiw

Brändli UB, Dowhanytsch J, Commarmot B (2008) Virgin Forest of Uholka. Nature Guide to the Largest Virgin Beech Forest of 
Europe A UNESCO World Heritage Site. Swiss Federal Resarch Institute WSL, Birmensdorf and CBR, Rachiv

Castello JD, Leopold DJ, Smallidge P (1995) Pathogens, patterns, and processes in forest ecosystems. Bioscience 45:16-24

Commarmot B, Bachofen H, Bundziak Y, Bürgi A, Ramp B, Shparyk Y, Sukhariuk D, Viter R, Zingg A (2005) Structures of virgin and managed beech forests in Uholka (Ukraine) and Sihlwald (Switzerland): a comparative study. For Snow Landsc Res 79(1/ 2):45-56

Duchesne LC, Anderson JB (1990) Location and direction of transcription of the 5S rRNA gene in Armillaria. Mycol Res 94:266-269

Dudka IO, Heluta VP, Hayova VP, Merezhko TO, YuYa T, Andrianova TV, Wasser SP (1997) Fungi. In: Diduh AA (ed) Biodiversity of the Carpathian Biosphere Reserve. Interecocentr, Kiev, pp 163-182 (in Ukrainian)

Farrell EP, Führer E, Ryan D, Andersson F, Hüttl PP (2000) European forest ecosystems: building the future on the legacy of the past. For Ecol Manag 132:5-20

Gardes M, Bruns TD (1993) ITS primers with enhanced specificity for basidiomycetes amplification to the identification of mycorrhizae and rusts. Mol Ecol 2:113-118

Garraway MO, Hüttermann A, Wargo P (1991) Ontogeny and physiology. In: Shaw CG, Kile GA (eds) Armillaria root diseases. Forest Service Agriculture Handbook No 691. Forest Service, United States Department of Agriculture, Washington DC, pp 21-46

Guillaumin JJ, Mohammed C, Berthelay S (1989) Armillaria species in the Northern temperate hemisphere. In: Morrison DJ (ed) Proceedings of the 7th International Conference on Root and Butt Rots. Forestry Canada, Vernon and Victoria, BC, pp 27-43

Guillaumin JJ, Mohammed C, Anselmi N, Courtecuisse R, Gregory SC, Holdenrieder O, Intini M, Lung B, Marxmuller H, Morrison D, Rishbeth J, Termorshuizen AJ, Tirro A, Vandam B (1993) Geographical distribution and ecology of the Armillaria species in Western Europe. Eur J For Pathol 23:321-341

Hamor F, Dovhanych Y, Pokynchereda V, Sukharyuk D, Bundzyak Y, Berkela Y, Voloshchuk M, Hodovanets B, Kabal M (2008) Virgin forests of Transcarpathia. Inventory and management. CBR, Rakhiv

Harrington TC, Wingfield BD (1995) A PCR-based identification method for species of Armillaria. Mycologia 87:280-288

Harrington TC, Worrall JJ, Baker FA (1992) Armillaria. In: Singleton LL, Mihail JD, Rush CM (eds) Methods for research on soilborne pathogenic fungi. American Phytopathological Society Press, St Paul, Minnesota, pp 81-85

Holah JC, Wilson MV, Hansen EM (1997) Impacts of a native rootrotting pathogen on successional development of old-growth Douglas fir forests. Oecologia 111:429-433

Jactel H, Nicoll BC, Branco M, Gonzalez-Olabarria JR, Grodzki W6, Långström B, Moreira F, Netherer S, Orazio C, Piou D, Santos H, Schelhaas MJ, Tojic K, Vodde F (2009) The influences of forest stand management on biotic and abiotic risks of damage. Ann For Sci 66:\#701 1-18. doi:10.1051/forest/2009054

Kaliszewski A, Lech P, Oszako T (2007) The occurrence of, and economic losses caused by Armillaria in the Western Carpathian Mts. Acta Mycol 42:219-233

Keča N, Bodles WJA, Woodward S, Karadžić D, Bojović S (2006) Molecular-based identification and phylogeny of Armillaria species from Serbia and Montenegro. For Pathol 36:41-57

Keča N, Karadžić D, Woodward S (2009) Ecology of Armillaria species in managed forests and plantations in Serbia. For Pathol $39: 217-231$

Kile GA, McDonald GI, Byler JW (1991) Ecology and disease in natural forests. In: Shaw CG, Kile GA (eds) Armillaria root diseases. Forest Service Agriculture Handbook No 691. Forest
Service, United States Department of Agriculture, Washington DC, pp 102-121

Kim MS, Klopfenstein NB, McDonald GI, Arumuganathan K, Vidaver AM (2000) Characterization of North American Armillaria species by nuclear DNA content and RFLP analysis. Mycologia 92:874-883

Korhonen K (1978) Interfertility and clonal size in the Armillariella mellea complex. Karstenia 18:31-42

Łakomy P (2006) New location of Armillaria mellea in Polish forests. Phytopathol Polon 41:83-86

Lamour A, Termorshuizen AJ, Volker D, Jeger MJ (2007) Network formation by rhizomorphs of Armillaria lutea in natural soil: their description and ecological significance. FEMS Microbiol Ecol 62:222-232

Legrand P, Guillaumin JJ (1993) Armillaria species in the forest ecosystems of the Auvergne (Central France). Acta Oecol $14: 389-403$

Legrand P, Ghahari S, Guillaumin JJ (1996) Occurrence of genets of Armillaria spp. In four mountain forests in Central France: the colonization strategy of Armillaria ostoyae. New Phytol 133:321-332

Lochman J, Sery O, Mikes V (2004) The rapid identification of European Armillaria species from soil samples by nested PCR. FEMS Microbiol Lett 237:105-110

Lonsdale D, Pautasso M, Holdenrieder O (2008) Wood-decaying fungi in the forest: conservation needs and management options. Eur J For Res 127:1-22

Lung-Escarmant B, Guyon D (2004) Temporal and spatial dynamics of primary and secondary infection by Armillaria ostoyae in a Pinus pinaster plantation. Phytopathology 94:125-131

Lushaj BM, Woodward S, Keča N, Intini M (2010) Distribution, ecology and host range of Armillaria species in Albania. For Pathol 40:485-499

Mallett KI, Maynard DG (1998) Armillaria root disease, stand characteristics, and soil properties in young lodgepole pine. For Ecol Manag 105:37-44

Maloy OC (1974) Benomyl-malt agar for the purification of cultures of wood decay fungi. Plant Dis Rep 58:902-904

Maphosa L, Wingfield BD, Coetzee MPA, Mwenje E, Wingfield MJ (2006) Phylogenetic relationships among Armillaria species inferred from partial elongation factor 1-alpha DNA sequence data. Australas Plant Path 35:513-520

Marçais B, Bréda N (2006) Role of an opportunistic pathogen in the decline of stressed oak trees. J Ecol 94:1214-1223

Marçais B, Caël O (2006) Spatial pattern of the density of Armillaria epiphytic rhizomorphs on tree collar in an oak stand. For Pathol 36:32-40

Marçais B, Wargo PM (2000) Impact of liming on the abundance and vigor of Armillaria rhizomorphs in Allegheny hardwood stands. Can J For Res 30:1847-1857

Morrison DJ, Pellow KW (2002) Variation in virulence among isolates of Armillaria ostoyae. For Pathol 32:99-107

Oliva J, Suz LM, Colinas C (2009) Ecology of Armillaria species on silver fir (Abies alba) in the Spanish Pyrenees. Ann For Sci 66:603-810

Parviainen J (2005) Virgin and natural forest in the temperate zone of Europe. For Snow Landsc Res 79:9-19

Pegler DN (2000) Taxonomy, nomenclature and description of Armillaria. In: Fox RTV (ed) Armillaria root rot: biology and control of honey fungus. Intercept, Andover, pp 81-93

Pérez-Sierra A, Whitehead DS, Whitehead MP (1999) Investigation of a PCR-based method for the routine identification of British Armillaria species. Mycol Res 103:1631-1636

Piri T, Korhonen K, Sairanen A (1990) Occurrence of Heterobasidion annosum in pure and mixed spruce stands in southern Finland. Scand J For Res 5:113-125 
Prospero S, Holdenrieder O, Rigling D (2003a) Primary resource capture in two sympatric Armillaria species in managed Norway spruce stands. Mycol Res 107:329-338

Prospero S, Rigling D, Holdenrieder O (2003b) Population structure of Armillaria species in managed Norway spruce stands in the Alps. New Phytol 158:365-373

Prospero S, Holdenrieder O, Rigling D (2004) Comparison of the virulence of Armillaria cepistipes and Armillaria ostoyae on four Norway spruce provenances. For Pathol 34:1-14

Prospero S, Holdenrieder O, Rigling D (2006) Rhizomorph production and stump colonization by co-occurring Armillaria cepistipes and Armillaria ostoyae: an experimental study. For Pathol 36:21-31

Rigling D, Blauenstein H; Walthert L; Rigling A, Kull P; Schwyzer A, Heiniger U (1998) Rhizomorph producing Armillaria species in Norway spruce stands in Switzerland. In: Delatour C, Guillaumin JJ, Lung-Escarmant B, Marçais B (eds) Proceedings of the 10th International Conference on Root and Butt Rots. Carcans-Maubuisson, Paris, pp 259-265

Rizun VB, Chumak VO (2008) Continuum-cycle concept of zooassemblage of climax (virgin forest) ecosystem (in Ukrainian). Scientific Bulletin of the Uzhgorod National University. Biology 24:24-33

Shaw CG III, Kile GA (1991) Armillaria root disease. Agricultural Handbook No 691. USDA Forest Service, Washington DC

Shelyag-Sosonko YR, Popovitch SY, Ustimenko PM (1997) Coenetic diversity. In: Diduh AA (ed) Biodiversity of the Carpathian Biosphere Reserve (in Ukrainian). Interecocentr, Kiev, pp 114-144

Stanosz GR, Patton RF (1991) Quantification of Armillaria rhizormorphs in Wisconsin aspen sucker stands. Eur J For Pathol 21:5-16
Tasenkevich LO, Stoyko CM, Tretyak PR (1982) UholskoShyrokoluzhanskyi massif. In: Stoyko CM, Tasenkvych LO, Milkina LI, Malinovsiy LA, Tretyak PR, Manko MP, Bezusko LG, Tsurick EI, Melnyk AS (eds) Flora and vegetation of the Carpathian Reserve. (in Ukrainian). Naukova Dumka, Kiev, pp 130-137

Tsopelas P (1999) Distribution and ecology of Armillaria species in Greece. For Pathol 29:103-116

Van der Pas JB (1981) A statistical appraisal of Armillaria root rot in New Zealand plantations of Pinus radiata. N Z J For Sci 11: 23-36

Veldman GM, Klootwijk J, Regt VCHF, Planta RJ, Branlant C, Krol A, Ebel JP (1981) The primary and secondary structure of yeast 26S rRNA. Nucleic Acids Res 9:6935-6952

Voitkiv P (2008) Acidic-alkaline properties of virgin forest's brown soil in the Ukrainian Carpathians (in Ukrainian). Visnyk of Lviv University, Ser. Geography 35:40-48

Voznyuk ST, Kuzmich PK (1984) Land improvement and fundamental hydrology (in Ukrainian). Textbook. Vysha Shkola, Lviv

Watling R, Kile GA, Burdsall HH Jr (1991) Nomenclature, taxonomy, and identification. In: Shaw CG, Kile GA (eds) Armillaria root diseases. Forest Service Agriculture Handbook No 691. Forest Service, United States Department of Agriculture, Washington DC, pp 1-10

White TJ, Bruns TD, Lee SB, Taylor JW (1990) Analysis of phylogenetic relationships by amplification and direct sequencing of ribosomal genes. In: Innis MA, Gelfand DH, Sninsky JJ, White TJ (eds) PCR protocols. Academic, New York, pp 315-322

Zolciak A, Bouteville RJ, Tourvieille J, Roeckel-Drevet P, Nicolas P, Guillaumin JJ (1997) Occurrence of Armillaria ectypa (Fr.) Lamoure in peat bogs of the Auvergne - The reproduction system of the species. Cryptogam Mycol 18:299-313 